\title{
6 Between protection and activation
}

\section{Shifting institutional arrangements and 'ambivalent' labour market policies in Vienna}

\author{
Byeongsun Ahn and Yuri Kazepov
}

\section{Introduction}

In the international debate, Austria has always been defined as a corporatist welfare model, characterised by a high degree of political cooperation and policy concertation between different interest groups (Österle and Heitzmann, 2020). In this 'partnership', the interest intermediation between political parties and the social 'partners' representing employees (the Chamber of Labour/the Federation of the Trade Union), and employers (the Economic Chamber/the Federation of Austrian Industries) were central to the formulation and implementation of economic and social policies based on a consensus-building model. Between 1957 and 1998, the core organisation of this partnership was the Parity Commission, an informal policy-making body comprising the four major social partners and members of the government (Lewis, 2002). Its subcommittees (on international affairs, economic and social affairs, prices and wages) and working parties delivered unanimous policy recommendations to the commission, around which the federal government formulated policies in conformity with the interests of the social partners ${ }^{1}$ (Gilbert, 1987). This recognition of their social role and the strong coordination led to relative consistency and stability in federal labour market policies, giving the social partners a quasi-monopoly in the corporatist policy-making process (Tálos and Hinterseer, 2019), also influencing the redistributive process.

However, in line with international trends (Natali et al., 2018), the bargaining power of the social partners have diminished in recent decades. This has been exacerbated, especially under the two conservative-right-wing federal governments (2000-2007/2017-2019) that initiated restructuring processes in the Austrian welfare system 
(Tálos and Hinterseer, 2019). Despite the anti-welfare rhetoric at the federal level, however, the path-dependent effects of the institutional evolution at the regional level have led to particular redistributive outcomes in Vienna. The institutional capacity of Vienna - being simultaneously a Bundesland and a municipality - and the longevity of the Socialist Democrats in power (see Chapter 2 by Mocca et al. in this volume) allowed the local government to actively formulate its own economic and social policies beyond the shifting priorities of the federal government. This particular outcome owes much to the decentralisation process of labour market policies that rescaled important responsibilities to the city level in the early 1990s, which empowered the local authority to innovate and develop a localised welfare model that maintained its inclusive characteristics. Contrary to centralised welfare services that remain strong in other European cities, for example in France (Revenu de solidarité active), Germany (Hartz IV), or the United Kingdom (Job Seekers Allowance), Vienna's new-found regulatory autonomy has, on the one hand, engendered new solutions to the structural problems of its local labour market, and on the other hand, allowed for the federal welfare retrenchment and restructuring in a more inclusive way.

\section{The structural context of institutional change}

Since the mid-1970s, the decline of the city's traditional manufacturing activities - both in terms of workplaces (1973/1981: $-17.9 \%)$ and employment (1973/1981: -19.4\%) - interrupted the employment growth that had characterised the post-war economic boom. The city's shrinking population (1971/1981: $-5.5 \%)$ - due to the end of the guest-worker recruitment programme, a low birth rate, aging population and the growing trend towards suburbanisation - further reinforced this trend. This situation was exacerbated by a lack of sectoral mobility for the displaced workers and the vulnerability of small- and medium-sized businesses vis-à-vis processes of economic restructuring and international competition. The joint effect of these trends brought about a myriad of new urban challenges. In this context, the development of active labour market policies and that of business investment programmes represented the main direct and indirect employment strategies. However, the conflict between the social partners throughout the 1980s and the lack of formal competence for policy formulation at the city level limited the ability to diversify Vienna's urban economy (Lechner et al., 2017). Simultaneously, the rapid expansion of the tertiary sector (e.g. in financial, insurance, and business services, and 
personal, social and public services) only partially compensated for job losses. This, in turn, hindered labour market reintegration of the displaced manufacturing workers into the expanding tertiary sector (for more on the structural shift in the Viennese economy during this period, see Chapter 7 by Riederer et al. in this volume).

As the unfavourable labour market situation continued in the 1980sboth regionally and nationally - attempts by the federal government to reshape access to welfare for the unemployed accelerated in two directions: (a) the retrenchment of the unemployment insurance scheme at the federal level; and (b) the decentralisation of active labour market policies to the regional level. Of course, the shift towards supply-side economics and the rescaling of the public employment service were widely observed elsewhere in this period. In contrast to the workfarist reforms in the Anglo-Saxon context, however, the high level of regulatory autonomy gained in Vienna enabled the city administration to institutionalise the welfare system, proving resilient to the shifting external environments. The emergence of new forms of governance in the ensuing decade allowed Vienna to provide demand-oriented services to those who were increasingly excluded from the retreating social protection system at the federal level. This outcome owes much to the interdependent institutional settings, featuring a high degree of complementarity between regional institutions, enabling the city administration to mobilise effectively against restrictive reform strategies formulated by the federal government.

\section{Pathway to regionalised active labour market policies (ALMPs) in Vienna}

In the mid-1980s, with the end of full employment in a time of global and national upturn in growth, a new political narrative around the unfavourable labour market situation emerged at the federal level. The new discourse portrayed structural unemployment as a lack of individual willingness, on the one hand, and a disparity between 'search' and 'matching', on the other hand (Tálos, 1987). As the focus of federal employment strategies shifted from economic policies to supply-side fiscal measures and restrictive budgetary policies, the relative importance of passive policies diminished, which in turn facilitated more experimental ALMPs. Employment action plans in the mid-1980s, namely Aktion 8,000, first introduced new regulatory principles and mechanisms for labour market reintegration of emerging vulnerable groups (e.g. youth, elderly and the long-term unemployed), through self-employment, community projects and social enterprises. Similar 
to employment schemes in other Western European countries at the time (Bonoli, 2010), these were aimed at creating jobs and subsidising costs in the secondary labour market, combined with new skills training. The success of these experimental programmes - creating around 11,500 jobs nationally between 1983 and 1995 (Lechner et al., 2017) initiated debates on the efficacy of the existing federal labour market administration, Arbeitsmarktverwaltung (AMV), which had attracted criticism for its bureaucratic management that had so far limited participation of regional actors, social partners, ${ }^{2}$ employers and private initiatives in the formulation of ALMPs.

In light of this, a semi-autonomous public employment service, Arbeitsmarktservice (AMS), was founded in 1994 by the federal government which, for the first time, rescaled the authority to implement labour market policies down to the regional level (Bundesland). The decentralisation and liberalisation of employment services to a diverse range of local actors allowed some level of regional flexibility to implement the employment objectives and strategies that had been formulated at the ministerial level. The federal AMS office, however, retained a top-down management structure and set qualitative and quantitative targets for their regional branches. This aimed to maintain a coherent employment policy framework between the federal and regional levels (Biffl, 1998). Despite the greater decision-making authority within the regional AMS branches, local governments could not autonomously formulate active labour market programmes to fit local needs and challenges. For this reason, Vienna initiated a regional employment service that was directly organised by the city administration (Atzmüller, 2009). As a result, the Vienna Employment Promotion Fund, Wiener ArbeitnehmerInnen Förderungsfonds (WAFF), was founded in 1995 as an initiative of the Federation of the Trade Union and the Chamber of Labour. This marked a path shaping moment for Vienna's localised ALMP system, featuring strong coordination and complementarity between the AMS Vienna, WAFF, and the social partners within both organisations. Since then, their institutional complementarity enhanced not only the policy capacity of each organisation, but also mutually compensated for their respective deficiencies: the operational ability of the AMS Vienna is limited to supervision of ALMPs for, and transfer payments to, 'registered' unemployed persons, whereas WAFF's vocational reorientation mainly aids those who are in employment. This supplementary form of complementarity that 'provides a missing ingredient' (Deeg, 2007) to one another has been key for the City's effective policy responses, especially when the regulative framework at the federal level was absent - or restrictive. 
Simultaneously, Austria's accession to the European Union in 1995 provided Vienna with a new opportunity to expand its ALMPs and diversify its policy outreach. The new multilevel governance setting promoted by the EU increased the City's institutional capacity, facilitated by greater responsibilities and resources, to respond to local labour market challenges more effectively. In the following year, the European Employment Strategy set new economic objectives that foresaw the development of a National Action Plan in 1998 and of Territorial Employment Pacts at the regional level in 1999. The latter aimed at translating the broader macroeconomic European objectives into more specific targets. The Lisbon and Stockholm strategies by the European Council identified, for instance, specific employment targets for disadvantaged social groups (at least $60 \%$ for women; $50 \%$ for those aged 55-64; and 70\% in total). In contrast to other European countries, the regional Territorial Employment Pacts in Austria were introduced by the federal government as an instrument for implementing the National Action Plan by enhancing the existing policy coordination between regional stakeholders in terms of policy design and fiscal management (Huber, 2004). By organising the pacts at the level of Bundesländer, at which necessary resources and substantial decision-making power are available, the Austrian National Action Plan foresaw greater autonomy for regional governments to formulate and implement localised employment policies, in accordance with a federal framework (Campbell, 2000). This led to a new mode of governance, based on collaborative policy making between the AMS Vienna and WAFF, whereby the regionalised federal employment service and the City's own employment fund was able to co-design innovative and needs-oriented policy measures for specific social groups. Following the Territorial Employment Pact - Vienna, the financial resources for activation measures at the City level made exponential growth, from 436,000 EUR in 1997 to 49 million EUR in 1999, financially supporting almost 10,000 people. The administrative capacity of WAFF to deliver services beyond the traditional welfare recipients enabled the expansion and diversification of activation and employment measures, not only in traditional skills training programmes (2,776; 13 million EUR), but also in wage subsidies $(3,275 ; 14$ million EUR), outplacement services (1,832; 11 million EUR), and employment in the secondary market (446; 5 million EUR) (Leitner et al., 2003). This structure was particularly effective in retaining employment of those in subsidised jobs, including some $70 \%$ who remained active in the labour market a year after the end of the programme (Leitner et al., 2003). 
In sum, the capacity building of regional actors in the early 1990s characterised the innovative aspect of the City's active labour market policy system. The financial and political autonomy of the regional institutions enabled the City of Vienna to formulate and implement active labour market policies beyond the conventional skills training and job matching measures, especially for those who were excluded from the federal social safety net. However, this faced new challenges between 2000 and 2006 during the conservative-right-wing federal government amid the growing 'work-first' approach to unemployment, and, more recently, between 2017 and 2019. At the City level, however, the workfarist attempt to roll back the redistributive policies and dismantle its fundamental structure was hindered by the strong veto opportunity of regional actors against such reforms, despite incremental changes.

\section{Localised outcomes of federal welfare retrenchment}

At the federal level, the late-1980s expansion of labour market protection and unemployment insurance-based benefits ended with the amendment of the Unemployment Insurance Act in 1993. The amendment foresaw limited access to benefits and coincided with the expansion of ALMPs and the decentralisation of public employment services to the regional level (Obinger and Tálos, 2006). A shift towards a more restrictive welfare state not only made access to unemployment benefit and assistance more difficult, by creating an institutionally structured downwards mobility path (see Figure 6.1). There was a decrease in the net replacement rates from unemployment benefits (from 57\% of the monthly net income in 1993 to 56\% 1995) and unemployment assistance (from $95 \%$ of the previously paid benefit to $92 \%$ in 1990), and more restrictive eligibility criteria were introduced (e.g. a longer minimum contribution period from 20 to 26 weeks in 1995 and additional sanctions in instances where individuals refused job offers). This trend was exacerbated under the conservative-right-wing federal government between 2000 and 2006, who introduced an extension to the minimum contribution period required before receiving unemployment benefits to 28 weeks and the reduction of the net replacement rate of unemployment assistance to its current rate (55\%).

Efforts to decrease the number of benefit recipients were accompanied by quantitative targets for the reduction of long-term unemployment and increased participation in activation programmes set by the European Employment Strategy. In 2004, a reform lifted the protection of benefit recipients, obliging them to take up jobs even if 


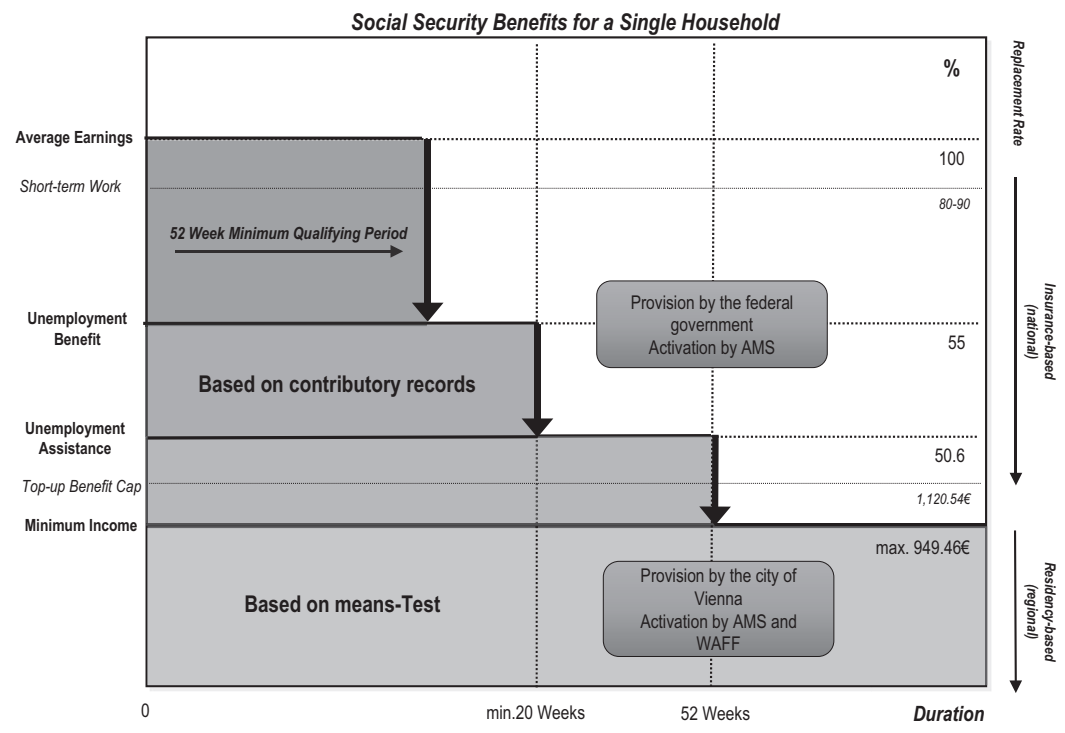

Figure 6.1 Access to unemployment insurance in Austria and Vienna, 2021. Source: Own Calculation based on Federal Ministry of Social Affairs, Health, Care and Consumer Protection; Public Employment Service Austria.

they mismatched their qualifications during the benefit period. ${ }^{3}$ Violations of such rules would imply sanctions, such as the temporary suspension of the benefit - first for six weeks, and then for eight weeks. This reform also made recipients ineligible for further transfer payments if they failed to attend meetings with street-level bureaucrats, as such actions were deemed to indicate an unwillingness to work and the reasonableness of their future employment. During this period, the influence of the Chamber of Labour and the Federation of Trade Unions on the management board of the AMS diminished, and more decisions were made by majority rule rather than full consensus (Tálos and Hinterseer, 2019). The pace and extent of liberalisation was less pronounced in Austria than in other Western European countries, such as Denmark, Germany, and the United Kingdom (Weishaupt, 2011), and was accompanied by a growing share of activation programmes in overall federal spending on labour market policies: from $18 \%$ in 2000 to $32 \%$ in 2004 . This growth was particularly visible in 'activating' financial incentives both to firms and the unemployed (130 million EUR in 2000; 747 million EUR in 2004) that were aimed at increasing the 
participation of unemployed people below the age of 25 and above 50 in qualification and employment programmes (Obinger and Tálos, 2006). Despite these growing financial efforts, however, the new policy orientation shows a paradigm shift and a trade-off, fostering shortterm, 'quick re-entry' labour promotion against labour protection. Whilst ALMPs continued to rise during the conservative-right-wing coalition, they did not target the specific needs of different vulnerable groups on the labour market, undermining the possibility of matching the changing dynamics of labour demand in the long run (Lutz and Mahringer, 2007; Figure 6.2).

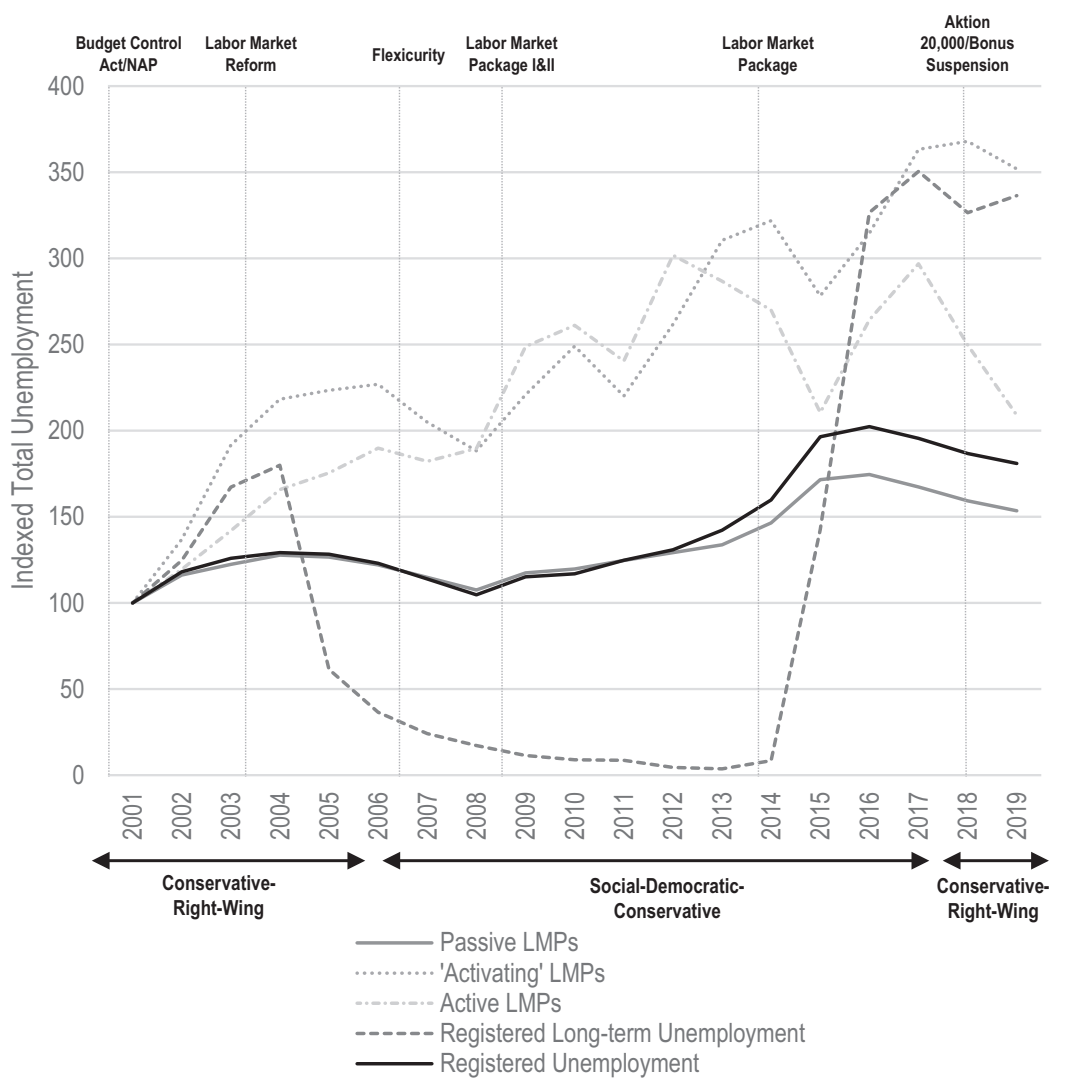

Figure 6.2 Indexed growth of active and passive LMPs in Vienna, 2001-2019 (2001=100).

Source: Public Employment Service Austria, Author's own elaboration. 
At the City level, this paradigm shift in the federal welfare system had a direct impact on the types of employment measures that were provided by the AMS Vienna. The restructuring of unemployment insurance produced a growing number of 'activating' financial incentives, and a doubling of training- and old age part-time subsidy recipients in the second year of the first conservative-right-wing federal government $(5,124$ in $2000 ; 10,288$ in 2001). Since the 2000 s, the share of 'activating' measures gradually increased from $8 \%$ of all unemployment-related benefit recipients in $1999(5,124)$ to $23 \%$ in 2006 $(23,343)$. The growth in part-time work subsidies for older workers has been especially high, which together with training subsidies and subsistence allowances, still account for the largest proportion of the 'activating' financial incentives spent to this day ( $35 \%$ in $2001 ; 29 \%$ in 2019 ). The impact of the growing 'activating' measures was mostly visible in the decline of long-time unemployment, especially in those over the age of 50. This trend reversed with new labour market reforms under the liberal-conservative federal government in 2015, which reoriented the employment strategies. The shifting focus of the federal employment strategies began to prioritise direct job-creation in community projects and social enterprises and offered financial incentives to firms that hired senior and long-term benefit recipients. This lowered the overall number of benefits recipients and increased that of the older and long-term unemployed in the secondary labour market. ${ }^{4}$

These developments ended under the second conservative-right-wing federal government in January 2018. Between 2017 and 2019, retrenchment at the federal level presented further challenges for the City's level of freedom in formulating localised ALMPs beyond the policy priorities of the federal government. One of the immediate impacts on labour force participation was the growth of long-term unemployment amongst those over the age of 55 and those who had not benefited from the favourable labour market situation that began in 2017. Contrary to the restrictive reforms of unemployment insurance in the 2000s, the reform proposals made by the second conservative-right-wing coalition aimed at eliminating unemployment assistance and at centralising the regional means-tested minimum income scheme. However, with the collapse of the federal government in 2019, a number of controversial reform proposals were revaluated, some of which were cancelled, including the abolition of unemployment assistance. Similar to Germany's Hartz IV Reform in 2005, it would have put those with limited social insurance contributions and an income below a given threshold directly under a new centralised minimum income scheme. The restructuring of the federal unemployment insurance is now suspended, 
and Vienna continues to provide a residency-based means-tested minimum income.

Whilst the contribution-based service provision of the AMS Vienna has been - and continues to be-susceptible to shifting policy priorities at the federal level, the localised welfare system based on the City's own redistributive institutions has provided Vienna with greater capacity to broaden its policy outreach. Despite the declining traditional corporatist welfare model during the two conservative-right-wing federal governments, the social partners within the AMS Vienna and WAFF retained relative autonomy in formulating and implementing employment and social policies. In contrast to the move towards tightening access and cutting benefits at the federal level, their institutional complementarity allowed the city administration to expand the boundaries of social protection and inclusion. For example, before the federal minimum income scheme was implemented in 2010, recipients of the regional social benefit were excluded from the activation programmes provided by the AMS, as these were - and continue to be - limited to recipients of unemployment insurance-based benefits. In 2009, a joint pilot project, Step2Job, from AMS Vienna and WAFF, co-financed by the European Social Fund, was launched to integrate regional social assistance recipients between the age of 21 and 64 into the activation programmes of the AMS. In coordination with the municipal social welfare office, the pilot gave 800 'top-up' income recipients access to personalised employment services; of these, $26 \%$ entered into employment with full compulsory insurance, and $44 \%$ into temporary employment. To date, the social benefit recipients were excluded from the federal welfare programmes because of a lack of contributory records. Following its expansion, the City of Vienna was able to implement more inclusive employment services for a broader group of vulnerable people under the means-tested minimum income scheme. Since the so-called refugee crisis, this has been especially crucial for the labour market integration of migrants, asylum seekers with subsidiary protection, and refugees - whose participation in the primary labour market has been limited by the increasing competition of low-skill and low-wage activities.

Another example of the City's institutional resilience to growing external pressures came shortly after the premature termination of the federal employment action plan, Aktion 20,000, which created 870 jobs in the secondary market for people over the age of 50 in Vienna in its first half-year. In response to its cancellation by the second conservative-right-wing federal government, the City of Vienna launched its own employment programme, Joboffensive 50plus, 
aimed at labour market reintegration for 500 people over the age of 50 who had been unemployed for more than three months. Vienna's steering capacity becomes clear through details: the programme covers the labour costs (up to $100 \%$ ) for employment in community projects and social enterprises, and up to $66.7 \%$ for employment in private businesses. Additionally, as the City's main coordinator of the European Employment Strategy, WAFF has been able to formulate needs-oriented activation programmes for those who would have otherwise been excluded from public employment services. The financial capacity of WAFF has increased in recent years, not least due to the resources from the European Social Fund, which corresponded to almost one-third of its total expenditure in 2018 (18.1 million EUR).

Similarly, the City's new minimum income scheme diverged from the federal reform plan that was set to restrict access for large families and refugees to non-contributory social assistance. Vienna's regional social protection system has been crucial for the growing number of refugees (ca. 37\% of all benefits recipients, as of 2019). This has been especially the case for asylum seekers with subsidiary protection, whose integration into the primary labour market, and therefore access to federal welfare programmes is limited. Unlike other Bundesländer that introduced the new federal social benefit scheme, as of 2021, Vienna has begun to provide asylum seekers with subsidiary protection with the residency-based benefit to the value of up to 949.46 EUR a month. This evidences the particular inclusiveness in Vienna's localised welfare system, as access to the minimum income scheme automatically qualifies the recipient for the contribution-based services provided by the AMS, which would otherwise only be available for those with employment records longer than six months in a year.

\section{Conclusions}

Since the early 1990s, emerging socioeconomic and political changes at multiple territorial levels have engendered both challenges and opportunities for Vienna's regulatory capacity and its ability to adequately address the increasing conditions of need. The shifting policy paradigm at the federal level has exacerbated the existing social inequalities in Vienna's urban labour market, in particular through increasingly restrictive conditionality for the social protection of marginalised, vulnerable groups outside of the labour force. Whilst the trend towards retrenchment and restrictions in social policies is a phenomenon that is not unique to Vienna or Austria, the regulatory framework at both levels have mediated the growing external 
pressures, which have in turn mitigated against the detrimental reform of its corporatist welfare system. At the City level, this owes much to the strong redistributive policy framework, of which the capacity for institutions to formulate their own employment and social policies have made it possible to expand the boundaries of social inclusion beyond those of the federal welfare state. Furthermore, a high level of coordination between different public institutions based on a consensus-building model contributes to the relative policy stability at the local level. This has been especially true for Vienna, where strong coordination between the regional branch of the federal employment service (AMS) and the City's own employment fund (WAFF) reversed their institutional deficiencies and complemented the policy capacity of one another. This resilience and capacity for innovation in the policy system has led to localised outcomes in the transition from welfare to workfare. This has not only slowed down the pace of abrupt policy changes, but has also allowed resistance against the fundamental restructuring of its institutional environment towards more exclusionary measures. Moreover, many of the reform proposals of the federal conservative-right-wing coalition were withdrawn by the end of 2019, when the new conservative-green coalition came to power.

The recent COVID-19 pandemic, however, has put the City to the test once again with the worst labour market crisis since the end of the Second World War. Thanks to the institutional capacity that characterises Vienna, with its strong corporatist welfare model, it is still able to mitigate external shocks through its localised regulatory framework, despite growing challenges. For instance, when Austria entered a lockdown in early March 2020, the City of Vienna launched its first Corona Aid Package on March 15th, complementing federal measures with a first emergency budget of 85 million Euro, including funds for small and medium-sized enterprises and for WAFF. Whilst one of the most crucial policy responses has been the expansion of the federal 'shorttime work' employment scheme, Kurzarbeit, ${ }^{5}$ the path-dependent effect of the City's local welfare system remained particularly relevant for the protection of socially vulnerable groups. This is particularly true for young people below the age of 25 , who are the largest share of participants in the AMS apprenticeship positions and training courses. As the gap between the available training programmes and young job seekers grew, the city government launched specific training packages for the promotion of youth labour mobility and youth labour market integration. This age group, alongside other benefit recipients excluded from the federal unemployment insurance scheme, have been further assisted by employment programmes through the 
new means-tested minimum income scheme, which gives them access to 'one-stop-shop' services that are provided both by the municipal social welfare office and the AMS Vienna. From this point of view, Vienna's localised welfare system continues to retain its inclusive dimension, resulting in a just redistributive outcome for a broader range of its citizens. The strong regulatory mechanisms, both at the federal and City levels, have prevented the worst labour market outcomes in the midst of the pandemic. However, a prolonged crisis and growing unemployment may alter the situation in the long term, putting the City of Vienna under increasing financial and political pressures on the city's minimum income scheme.

\section{Notes}

1 Whilst the Parity Commission declined after Austria's accession to the EU in 1995 and was made defunct from 1998, the Advisory Council for Economic and Social Affairs remains, providing a platform for policy coordination between the four social partners.

2 The social partners previously had no formal decision-making competence in the AMV.

3 Whilst the duration of the job protection was reduced to 100 days, any job offered to the recipient was considered to be 'acceptable', as long as the wage covered at least the $80 \%$ of the calculation base of the previously received unemployment benefit, and the commute does not exceed 2 hours for full-time and 1.5 hours for part-time employment contracts. After 120 days of the benefit payment, this is reduced to $75 \%$.

4 Since the Flexicurity Law Package in 2007, the legal criteria for the 'reasonableness' of labour market reintegration were extended to temporary employment in the secondary labour market via community projects and social enterprises.

5 It covers up to $90 \%$ of salaries for the amount of reduced work-hours in order to avoid mass layoffs. In March alone, the share of short-term working covered more than $58.6 \%$ of all activation programs, which subsidised 112,686 jobs.

\section{References}

Atzmüller, R., 2009. Institution building and active labour market policies in Vienna since the 1990s. International Journal of Sociology and Social Policy, 29(11/12), pp. 599-611.

Biffl, G., 1998. Placement activities in Austria before and after. WIFO Working Papers, 103, pp. 1-54.

Bonoli, G., 2010. The political economy of active labor-market policy. Politics \& Society, 38(4), pp. 435-457.

Campbell, M., 2000. Lokale Partnerschaften in Österreich: Eine Studie im Rahmen des LEED-Programmes der OECD. Wien: Bundesministerium für Wirtschaft und Arbeit. 
Deeg, R., 2007. Complementarity and institutional change in capitalist systems. Journal of European Public Policy, 14(4), pp. 611-630.

Gilbert, R.W., 1987. Austria's social partnership: A unique extralegal system of labor-management cooperation. The Labor Lawyer, 3(2), pp. 311-322.

Huber, P., 2004. Evaluating territorial employment pacts: Methodological and practical issues the experience of Austria. In: OECD, ed. 2004. Evaluating local economic and employment development: How to assess what works among programmes and policies. Paris: OECD Publishing, pp. 369-380.

Lechner, F., Reiter, W., Wetzel, P., et al., 2017. Die experimentelle Arbeitsmarktpolitik der 1980er-und 1990er-Jahre in Österreich: Rückschlüsse und Perspektiven für Gegenwart und Zukunft der aktiven Arbeitsmarktpolitik. Wien: Arbeitsmarktservice Österreich.

Leitner, A., Wroblewski, A., Hofer, H., et al., 2003. Aktive Arbeitsmarktpolitik im Brennpunkt IX: Arbeitsmarktpolitische Wirkungen des TBP. Wien: Arbeitsmarktservice Österreich.

Lewis, J., 2002. Austria in historical perspective: From civil war to social partnership. In: Berger, S. and Compston, H., eds., 2002. Policy concertation and social partnership in Western Europe: Lessons for the 21st century. New York: Berghahn Books, pp. 19-35.

Lutz, H. and Mahringer, H., 2007. Wirkt die Arbeitsmarktförderung in Österreich? Überblick über Ergebnisse einer Evaluierung der Instrumente der Arbeitsmarktförderung in Österreich. WIFO Monatsberichte, 3, pp. 199-218.

Natali, D., Pavolini, E. and Vanhercke, B., eds., 2018. Occupational welfare in Europe: Risks, opportunities and social partner involvement. Brussels: European Trade Union Institute (ETUI); European Social Observatory (OSE).

Obinger, H. and Tálos, E., 2006. Sozialstaat Österreich zwischen Kontinuität und Umbau: Eine Bilanz der ÖVP/FPÖ/BZÖ-Koalition. Vienna: VS Verlag für Sozialwissenschaften.

Österle, A. and Heitzmann, K., 2020. Austrification in welfare system change? An analysis of welfare system developments in Austria between 1998 and 2018. In: Blum, S., Kuhlmann, J. and Schubert, K., eds., 2020. Routledge handbook of European welfare systems. Abingdon, Oxon, New York: Routledge, pp. 21-37.

Tálos, E., 1987. Arbeitslosigkeit und beschäftigungspolitische Steuerung. In: E. Tálos and M. Wiederschwinger, eds. 1987. Arbeitslosigkeit: Österreichs Vollbeschäftigungspolitik am Ende? Vienna: Verlag für Gesellschaftskritik, pp. 91-166.

Tálos, E. and Hinterseer, T., 2019. Sozialpartnerschaft: Ein zentraler politischer Gestaltungsfaktor der Zweiten Republik am Ende? Innsbruck: Studienverlag.

Weishaupt, J.T., 2011. Social partners and the governance of public employment services: Trends and experiences from Western Europe. Geneva: International Labour Office. 